\title{
Vernonia amygdalina: An Underutilized Vegetable with Nutraceutical Potentials - A Review
}

\author{
Oseni Kadiri *, Babatunde Olawoye
}

Department of Food Science and Technology, Obafemi Awolowo University, PMB 13, Ile-Ife, Osun State, Nigeria A R T I C L E I N F O

\section{Article history:}

Received 30 October 2015

Accepted 24 August 2016

Available online, ISSN: 2148-127X

\section{Keywords:}

Vernonia amygdalina

Nutritional

Phytochemical

Antioxidant

Phytochemical

Antibacterial

Hepatoprotective

\section{A B S T R A C T}

In recent years, studies have been focus not only on the nutritional properties of Vernonia amygdalina, but its pharmacological, medicinal and antioxidant values. The antioxidant, antidiabetic, hepatoprotective, haematological, antiplasmodial, antimicrobial, anticancer, anti-inflammatory, pharmacological and medicinal value of Vernonia amygdalina is no longer in doubt and is comprehensively documented in this study. Some studies attribute its medicinal properties to its phytochemical compounds while other studies link its health benefits to its bioactive components. It is expected that this review will be useful to researchers, agriculturists and herbal medical practitioners and improve interest in the study and utilization of this plant in other part of the globe where it is not presently cultivated or utilize. Relevant information was obtained from online resources such as Google Search, Google Scholar, PubMed and Medline. Only literature highlighting the nutritional, medicinal, pharmacological, and antioxidant activities of the plant were selected for this review.

${ }^{\text {"} C o r r e s p o n d i n g ~ A u t h o r: ~}$

E-mail: kadirioseni@yahoo.com

\section{Introduction}

Vernonia amygdalina is a common shrub or small tree that grows in tropical Africa. They are well distributed also in Asia and are commonly found along drainage lines and in natural forest or commercial plantation. It belongs to the Asteraceae family and popularly called 'African bitter leaf' in Africa, 'Ewuro' in Yoruba, 'Etidot' in Ibibio, 'Onugbu' in Igbo, 'Ityuna' in Tiv, 'Ilo' in Igala, 'Oriwo' in Edo, 'Chusar-doki' in Hausa, 'Grawa' in Amharic and 'Omubirizi' in south- western Uganda. The leaves are green in colouration with a characteristic odour and bitter taste (Akpaso et al., 2011). The leaves of VA are used as soup condiments after washing and boiling to get rid of the bitter taste (Hamzah et al., 2013). Specifically, it is used to prepare the popular Nigerian bitter leaf soup, "Onugbo" and as spice in the Cameroon dish called "Ndole" (Ho et al., 2012). In some part of the Africa continent like Nigeria, the plant is made into tonic and drank for medicinal purposes (Igile et al., 1994). Other popular use of Vernonia amygdalina in Africa includes traditional treatment of diseases, such as malaria, infertility, diabetes, gastrointestinal problems and sexually transmitted diseases (Farombi and Owoeye, 2011). Ethno-medical use of Vernonia amygdalina in the treatment of ailments such as veneral diseases, gastrointestinal problems and malaria had also been reported (Kambizi and Afolayan, 2001; Huffman, 2003; Huffman and Seifu, 1989). Their traditional use is not limited to human alone as it added to horse feed to provide a strengthening or fattening tonic called 'Chusan Dokin' in Northern Nigeria (Hamzah et al., 2013). In another instance, Vernonia amygdalina had been reported in the treatment of parasite related disease in wild chimpanzee in Tanzania (Huffman and Seifu, 1989). Anthelmintic, antimalarial, antitumourigenic as well as bacteriostatic and bactericidal effect on some bacteria properties of Vernonia amygdalina extracts has been employed (Abort and Raserika, 2003; Izevbigie et al., 2004).

Specifically, Nwajo (2005) reported the hypoglycaemic and hypolipidaemic effect of the leave extracts in vivo. Also, traditional care givers recommend its aqueous extract for the treatment of their patients in varieties of ailment ranging from emesis, nausea, diabetes, loss of appetite, dysentery, gastrointestinal tract problems to sexual transmitted diseases and diabetes mellitus among others (Argheore et al.,1998). These observations necessitate studies to ascertain the efficacy of different part of the plant in managing a wide array of ailments claims as well as it nutraceutical values. 


\section{Phytochemical Composition of Vernonia Amygdalina}

Phytochemicals are natural occurring bioactive compounds known for their health benefits. They are majorly responsible for the colour, flavour and aroma of fruits and notably vegetables. Bioactive compounds have been shown to prevent the advent of many chronic diseases such as cancer, diabetes, heart and Alzheimer's disease. The presence of phytochemicals such as saponins, flavonoids, alkaloids and hydrocyanic acids in the roots and barks extracts of Vernonia amygdalina was reported by Eyong et al. (2011). This study agrees with the report of Argheore et al. (1998) on the study of the leaf extracts of Vernonia amygdalina on detection of phytochemicals. Phytochemicals in Vernonia amygdalina contains bioactive compounds which are anti-viral in nature as well as having prophylactic and therapeutic effect against cancer cells (Cheng et al., 2002; Noumedem et al., 2013). While the report of Ghamba et al. (2014) establishes the presence of phytochemicals in Vernonia amygdalina, Udochukwu et al. (2015) evaluated the concentration $(\mathrm{mg} / 100 \mathrm{~g})$ of some of this aforementioned phytochemicals and observed Vernonia amygdalina to contained higher levels of bioactive compounds than Ocium gratissimum save for phytate and cyanogenic glycosides (Table 1).

\section{Nutritional Composition}

Quite a number of researches have established the nutritional content of Vernonia amygdalina. Proximate composition of Vernonia amygdalina reveals the presence of protein, carbohydrate, moisture, ash, fibre and fat as reported by Argheore et al. (1998). The analysed moisture content (\%) as reported by Argheore et al. (1998) was $10.55 \%$ which was higher than that reported $(10.02 \%)$ by Asaolu et al. (2012). Variation was suggested to be due to soil nutrients and environmental factors which have effects on the nutrients availabilities for plants. The crude fibre content of Vernonia amygdalina is $8.78 \%$ which is within the ranged for some Nigerian vegetables. Also, ash content indicates $4.28 \%$ which is lower than values reported by Asaolu et al. (2012) for bitter leaf (9.56\%) and scent leaf (13.01\%). The presence of ash in bitter leaf is a confirmation of the presence of mineral elements. The crude protein $(18.75 \%)$ was higher than the protein contents of some leafy vegetables such as Momordica balsamina (11.29\%). This result affirms reports of Ezekiel et al. (2015), Kokwaro et al. (2009) and Sodimic et al. (2006). Table 2.0 shows the nutritional composition of dried Vernonia amygdalina.

Ezekiel et al. (2009) observes minerals contents in Vernonia amygdalina in the trend;

$$
\mathrm{K}>\mathrm{Na}>\mathrm{Ca}>\mathrm{Mg}>\mathrm{Fe}>\mathrm{Zn}>\mathrm{Cu}>\mathrm{Mn}
$$

Potassium was the predominant mineral element detected while manganese was the least detected minerals element. Inorganic mineral elements such as potassium and calcium are known to play important roles in the maintenance of normal glucose-tolerance and in the release of insulin from beta cells of islets of Langerhans which helps to control the glucose level of the human body (Kadiri, 2015).

Table 1 Phytochemical Components of Ethanoic Extracts of Vernonia amygdalina $(\mathrm{mg} / 100 \mathrm{~g}) *$

\begin{tabular}{l|cc}
\hline \multicolumn{1}{c|}{ Phytochemicals } & $\begin{array}{c}\text { Vernonia } \\
\text { amygdalina }\end{array}$ & $\begin{array}{c}\text { Ocimum } \\
\text { gratissimum }\end{array}$ \\
\hline Oxalate & 3.84 & 0.75 \\
Phytate & 3.95 & 5.56 \\
Tannins & 9.62 & 2.84 \\
Saponins & 5.97 & 3.52 \\
Flavonoid & 4.89 & 1.74 \\
Cyanogenic glycoside & 1.11 & 2.38 \\
Alkaloids & 2.16 & 1.07 \\
Anthraquinone & 0.14 & 0.31 \\
Steroid & 0.38 & 0.30 \\
Phenol & 3.24 & 0.73 \\
\hline
\end{tabular}

*Source Udochukwu et al. (2015)

Table 2 Nutritional Analysis (mg/100g dry matter) of bitter leaf (Vernonia amygdalina)*

\begin{tabular}{l|c}
\hline \multicolumn{1}{c|}{ Nutrient } & Value $(\mathrm{g} / \mathrm{mg})$ \\
\hline Crude protein & $23.10 \mathrm{~g}$ \\
Ash & $17.13 \mathrm{~g}$ \\
Cellulose & $12.31 \mathrm{~g}$ \\
Edible portion & $100 \mathrm{~g}$ \\
Fats & $0.4 \mathrm{~g}$ \\
Protein & $5.2 \mathrm{~g}$ \\
Water & $82.0 \mathrm{~g}$ \\
Energy & $218 \mathrm{~g}$ \\
Carbohydrates & $10.0 \mathrm{~g}$ \\
Dietary Fibre & $1.5 \mathrm{~g}$ \\
Calcium & $145 \mathrm{mg}$ \\
Phosphorus & $6.7 \mathrm{mg}$ \\
Iron & $5.0 \mathrm{mg}$ \\
Zinc & $85.0 \mathrm{mg}$ \\
Manganese & $710.0 \mathrm{mg}$ \\
Ascorbic acid & $5.1 \mathrm{mg}$ \\
\hline
\end{tabular}

*Source : Sodimic et al. (2006) ; Kokwaro et al. (2009)

\section{Antioxidant Properties}

There has been increase scientific interest in antioxidants from plant sources in recent times. Antioxidants inhibit deleterious effects of free radicals in human body and deterioration of fats without corresponding side effects when compared with synthetic antioxidants. They are compounds that inhibits or stop the actions of these radicals and its reactive oxygen species (ROS) known for the development of disease originating from oxidative stress. Quite a number of researchers in the field of medical sciences have observed free radical scavenging ability and antioxidant property in Vernonia amygdalina. Vernonia amygdalina have been established to possess antioxidant properties which correlates to its medicinal properties. They are plants known to play dietary as well functional roles in disease prevention. Antioxidant activities of bioactive compounds isolated 
from Vernonia amygdalina leaves have been established from various studies (Igile et al., 1994; Farombi and Owoeye, 2011; Ho et al., 2012; Udochukwu et al., 2015).

Comparative studies between the methanolic and aqueous extracts of Vernonia amygdalina and Talinum triangulare leaves reveals Vernonia amygdalina to possess higher antioxidant properties, phyto-nutrients and longer shelf life hence it's common use and acceptability in folkloric and trado-medicine (God's will et al. 2010). Methanolic extracts of Vernonia amygdalina shows potent antioxidant properties in a study by Adesanoye and Farombi (2014). Correlation coefficients was observed between total phenolic/flavonoid content and the antioxidant and free radical scavenging activities of the plants which implies that these properties are dependent on the flavonoid and phenolic contents of the plant.

DPPH (2, 2-diphenyl 1-picrylhydrazyl) assay of the methanolic extract of Vernonia amygdalina leaves reveals significant antioxidant properties (Ezekiel et al., 2015). The antioxidant properties exhibited by the leaves may explain the antioxidant benefits which explains it usefulness in the prevention of diseases caused by free radicals and reactive oxygen species (ROS). Also, comparative study of the ethanolic extracts of Vernonia amygdalina and Ocimum gratissimum leaves showed significant antioxidant activity $(\mathrm{P}<0.05)$ when compared with antioxidant standards like ascorbic acid in a study by Udochukwu et al. (2015). Significant content of phenol and flavonoid were also estimated even though detected values for Ocimum gratissimum leaves showed significant higher amount than Vernonia amygdalina leaves. These results substantiate the medicinal value of these vegetables. Vernonia amygdalina leaf extracts was also shown to increase in vivo antioxidants activities of test rats in an in vivo antioxidants assay (Argheore et al. 1998). Antioxidant and anti-diabetic properties of sequential petroleum ether, chloroform, methanol and water extracts of Vernonia amygdalina based on the chemical composition of the most effective anti-diabetic extract was reported using DPPH and ABTS radical scavenging as well as FRAP assays by Akpaso et al. (2011). Extracts of the various solvent extractions were observed to show a consistent dose-dependent trend of potent antioxidant activity in the following solvents: water extract $>$ methanol extract $>$ chloroform extract $>$ and petroleum ether extracts. The extracts were also observed to inhibit DPPH activity in a dose-dependent manner with significantly higher potencies in the polar extracts compared to the non-polar extracts. Omoregie and Osagie (2012) reported the in vitro and in vivo antioxidant effects of methanolic extracts of six locally consumed Nigeria plants on nutritionally-stressed rats. These plants include; Vernonia amygdalina, Crassocephalum rubens, Jatropha tanjorensis, Amaranthus hybridus, Talinum triangulare and Gnetum africana. Laboratory test rats were exposed to nutritional oxidative stress using a low protein diet and In vivo antioxidant activities assay was carried out on the test animals and the control animals. Plant extracts were observed to exhibit comparable DPPH free radical scavenging ability in a dose-dependent manner. Extracts treated rats showed normal levels of antioxidant enzymes (superoxide dismutase, catalase, vitamins $\mathrm{E}$ and $\mathrm{C}$ ) as well as high level of malonaldehyde probably due to the bioactive principles inherent in them. The overall antioxidant capacity of the extracts suggested a positive correlation as well as synergistic effects with respect to the DPPH scavenging activity, total phenol, flavonoid and proanthocyanindin components of the extracts. This they observes might indicate that the components are more likely to contribute to the antioxidant potential of the extracts and confirms local claims on the efficacy of the plants leaves (Omoregie and Osagie, 2012). More recent studies by Ekaluo et al., 2015, Udochukwu et al., 2015 and Ezekiel et al., 2015 affirms previous studies on the antioxidant properties of Vernonia amygdalina leaves extracts.

\section{Pharmacological Properties}

Vernonia amygdalina leaves have been used by traditional medical practitioners in the treatment of malaria over the decade. WHO (2003) recognises the role played by traditional medicine in rural communities in the provision of health care in the absence of an efficient public health care system. Anoka and Njan (2013) reports the leaf extract of Vernonia amygdalina leaves to treat wister rats infected with rodent malaria (Plasmodium berghei). The leaves extracts also showed analgesic activity with clear and significant anti-plasmodia effects in mice. Toxicity in rats, incidental findings below or above standard reference levels were all within control values based on historical reference ranges. It was suggested that the findings might explain the pharmacological basis for the successes in pain and malaria treatment claimed by traditional healers who use Vernonia amygdalina.

\section{Medicinal Properties}

Traditional health workers in Africa recommend the aqueous extracts of Vernonia amygdalina as treatment for varieties of ailments ranging from emesis, nausea, diabetes, loss of appetite, dysentery and other gastrointestinal tract problems to sexually transmitted diseases and diabetes mellitus among others (Argheore et al. 1998). Some of these claims have been verified experimentally and documented while others are yet to be validated. Figure 1.0 shows some of this traditional uses.

Farombi and Owoeye (2011) observes phytochemicals compounds such as saponins and alkaloids, terpenes, steroids, coumarins, flavonoids, phenolic acids, lignans, xanthones, anthraquinones, edotides, sesquiterpenes extracted and isolated from Vernonia amygdalina to elicit various biological effects in humans including cancer chemoprevention. The chemopreventive properties of Vernonia amygdalina was attributed to their abilities to scavenge free radicals, induce detoxification, inhibit stress response proteins and interfere with DNA binding activities of some transcription factors. 


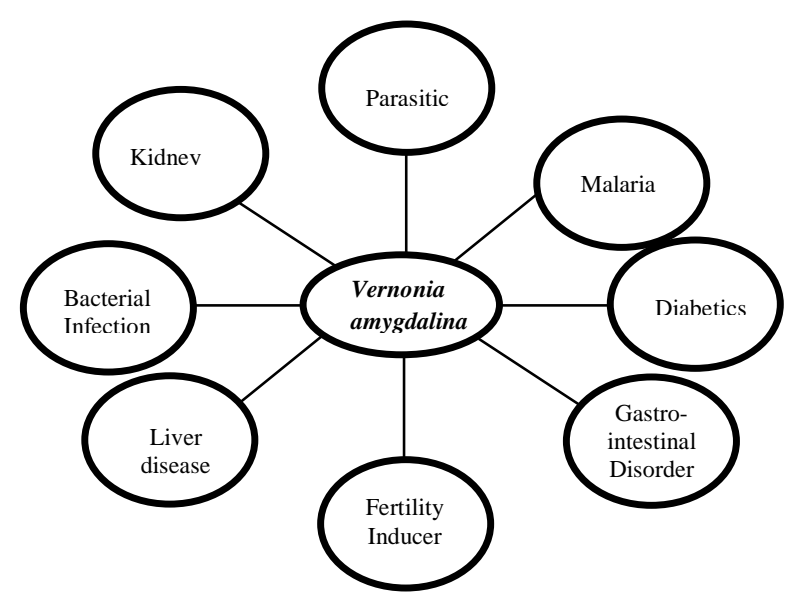

Figure 1 Traditional use of Vernonia amygdalina (Bitter leaf)

Isolated dotides and sesquiterpene lactones form the leaf of Vernonia amygdalina are now known to elicit remarkable antioxidant and chemo-preventive properties in cell cultures and rodent models. Prominent among the biochemical and molecular mechanisms of action of these isolated compounds were elevation of phase II enzymes activities, inhibition of cell proliferation and suppression of pro-inflammatory mediators. These mechanisms were also observes to play pivotal role in chemoprevention which appears to be a more pragmatic and rational approach to prevention of cancer. Vernonia amygdalina leaf along with Garcina kola were said to be possible future chemo-preventive agents though necessary longterm clinical trials was suggested to verify this finding. Extracts of Vernonia amygdalina had also been reported to reduce lipid and cholesterol profile, both risk factor in hyperlipidaemia and atherosclerotic plague. Extracts of Vernonia amygdalina causes a slight decrease in the lipid profile of experimental rats (Argheore et al., 1998) which is in agreement with previous findings of Erasto et al., 2007. Administration of an aqueous Vernonia amygdalina leaf extract to hyperlipidaemia animals decrease plasma total cholesterol, low density lipoprotein, and very low density lipoprotein in a study conducted by Oboh and Enobhayisobo, 2009. These findings shows that aqueous Vernonia amygdalina leaf extract may be useful in the control of blood lipids, prevention and treatment of coronary heart disease.

\section{Antidiabetic Properties}

The antithrombotic and hypoglycaemic effects of Vernonia amygdalina leaf extract, its hypolipidaemic effect in diabetic and normoglycemic hyperlipidaemia have been reported (Adaramoye et al., 2008; Nwanjo, 2005). Vernonia amygdalina extracts have rescinding effect on blood and serum glucose of diabetic rats. In a study by Akpaso et al., 2011, the chloroform extracts of Vernonia amygdalina was observed to have the highest blood $(23.5 \%)$ and serum $(21.4 \%)$ glucose-lowering effects $(\mathrm{P}<0.05)$ in diabetic rats after a 14-day administration. This study agrees with the studies of previous findings by Nwanjo (2005) on the antidiabetic effect of the aqueous extract Vernonia amygdalina in streptozotocin induced diabetic rats and the antidiabetic effect of the combined leaf extracts of Vernonia amygdalina (bitter leaf) and Gongronema latifolium on the pancreatic $\beta$ - cells of streptozotocin - induced diabetic rats. Their findings substantiate the beneficial effect of Vernonia amygdalina in human nutrition and its likely role in the management of diabetes though there is need for further studies to substantiate these claims.

\section{Antibacterial Properties}

The aqueous extract of the leaves has inhibitory effect on the growth of gram +ve bacterium; Staphylococcus aureus and the gram -ve bacterium; Escherichia coli in a report by (Oboh and Enobhayisobo, 2009). Staphylococcus aureus and Escherichia coli exhibited sensitivity to Vernonia amygdalina extract, each giving a zone of inhibition of $0.8 \mathrm{~cm}$. This agrees with more recent report of Udochukwu et al. (2015). Water and Ethanol extracts of Vernonia amygdalina have been reported to possess antibacterial action against pure culture of clinical bacterial isolates. Udochukwu et al. (2015) reported the inhibitory effect of Vernonia amygdalina and Ocimum gratissimum extracts against pure cultures of clinical isolates of Staphylococcus aureus, Pseudomonas aeruginosa and Escherichia coli. Water and ethanol were used for the plants' active constituents' extraction and method employed was the Agar diffusion method in the determination of the antibacterial effects of both plant extract on the test organisms. The minimum inhibitory concentrations (MIC) of water and ethanol extracts on the test organisms ranged between $25-50 \mu \mathrm{L} / \mathrm{mL}$ (Table 4). Similarly, the zone of inhibition of the plant extract diameters at concentration of $100 \mu \mathrm{L} / \mathrm{mL}$ ranged between $7.5-5.0 \mathrm{~mm}$ and $11.5-7.0 \mathrm{~mm}$ for water and ethanol extracts respectively on the test organisms (Udochukwu et al., 2015). Water extract of Vernonia amygdalina was more effective on Pseudomonas aeruginosa than of Ocium gratissimum. Ethanolic extract of Ocium gratissimum was also reported to be more effective than ethanolic extract of Vernonia amygdalina on same bacteria strains. Extracts showed zones of inhibition higher than some selected antibiotics (Amoxicillin, Tetracycline, Doxycycline, Ampiclox and Septrin) at $400 \mu \mathrm{L} / \mathrm{mL}$. The author justify the use of the leaf as therapeutic agent in traditional medicine practice and suggested ethanol extracts at a concentration up to $100 \mu \mathrm{L}$ $/ \mathrm{mL}$ as a better treatment margin. A prior study by Ghamba et al. (2014) on the leaves of Vernonia amygdalina (Table 3.0) extracts showed strong antimicrobial activities against tested clinical isolates which agrees with recent study of Udochukwu et al. (2015) on the antimicrobial activities of Vernonia amygdalina leaf extract. Ghamba et al. (2014) suggested that the antimicrobial activity of these leaves makes it a potential herb for drug development due to its inhibition effects on bacterial growth. Foo et al. (2014) suggested contradictory view on the effects of Vernonia amygdalina extracts on E.coli strains though difference in 
susceptibility was said to be likely due to genetic diversity of the pathogen which gives rise to different resistant mechanisms (Noumedem et al., 2013).

Table 3 Antimicrobial activities of Vernonia amygdalina (Bitter leaves) aqueous leaves extracts on selected clinical isolates*

\begin{tabular}{l|c}
\hline \multicolumn{2}{c}{ Zones of Inhibition (mm) } \\
\hline Test Organism & Aqueous extracts \\
\hline Escherichia coli & 12.5 \\
Pseudomonas aeruginosa & 12.2 \\
Klebsiella spp & 11.8 \\
Staphylococcus aureus & 11.4 \\
Streptococcus spp & 0.0 \\
Candida albicans & 11.8 \\
\hline *Source: Ghamba et al. (2014)
\end{tabular}

\section{Hepatoprotective Effects}

The possible ability of Vernonia amygdalina extracts in preventing liver and kidney damage in mice and albino rats have been evaluated and reported in recent studies. Minari (2012) associated the ability of Vernonia amygdalina extracts in retarding damage to liver and kidney to their antioxidant properties. This was achieved by accessing the hepatoprotective activities of methanolic extracts of the leaves of Vernonia amygdalina against carbon tetrachloride-induced hepatotoxicity and oxidative stress in albino rats. Administration of carbon tetrachloride $(\mathrm{CCl} 4)$ to rats significantly reduced the activities of liver and kidney ALT and AST. Simultaneous treatment of $\mathrm{CCl} 4$ injection with oral administration of the methanolic extract also reversed hepatic damage via reduction marker enzymes like ALT, AST, ALP, in both the liver and kidney. Similar observations were also made by Farombi and Owoeye (2011) who reported accelerated reversion of hepatic damage in mice via reduction of liver marker enzymes like ALT, AST, ALP, lactate dehydrogenase when different doses of methanolic extracts of Vernonia amygdalina were administer. Similarly, increased antioxidant enzymes such as superoxide dismutase, glutathione S-transferase and reduced glutathione concentration and catalase activity at different doses of the methanolic extract of Vernonia amygdalina were observed. These studies agrees with previous report of Iwaloku et al. (2006) on the antioxidant properties of Vernonia amygdalina in acetaminophen induced hepatotoxicity in mice. The preventive roles of the antioxidant properties of Vernonia amygdalina in hepatotoxicity and oxidative stress in are clearly stated by these studies (Minari, 2012; Farombi and Owoeye, 2011 and Iwaloku et al., 2006).

\section{Conclusion}

The nutraceutical potential of Vernonia amygdalina is no longer in doubt. It is now established that this plant possesses beneficial antioxidant, hepatoprotective, antibacterial, antidiabetic, medicinal and pharmacological properties which confirms claims by local health givers though clinical test using human still needs to be carried out. As studies continue to focus the nutraceutical properties of this plant, it is expected that more of its medicinal and nutritional properties of the plant will be unravelled. Consumption and cultivation of these vegetable in other part of the world should be encouraged based on its established nutritional as well as it medicinal properties. Research into the development of nutraceutical drugs from Vernonia amygdalina should be initiated and encouraged based on nutraceutical attributes. Researchers should also focus their investigation on the isolation and identification of bioactive components of this plant. It is important to identity the components that are responsible for each of the identified medicinal and pharmacological properties of the plant. This may form a basis for the discovery of novel drugs from the plants. Further study should also be conducted on the nutritional, medicinal and antioxidant potentials of other parts of the plant such as the stem, roots and bark.

\section{References}

Abort AO, Raserika BH. 2003. In vivo antimalarial activity of Vernonia amygdalina. British J of Biomed Sci., 60: 89-91.

Adaramoye OA, Akintayo O, Achem J, Fafunso M. 2008. Lipidlowering effects of methanolic extract of Vernonia amygdalina leaves in rats fed on high cholesterol diet.Vas Health \& Risk Manage., 4: 235-241.

Adesanoye OA, Farombi EO. 2014. In Vitro Antioxidant Properties of Methanolic Leaf Extract of Vernonia Amygdalina Del. Niger J Physio Sci., 29: 091-101

Adewole E, Ojo A, Ogunmodede OT and Adewumi DF. 2015. Antioxidant Activities and Nutritional Composition of Vernonia Amygdalina. Int J Basic Appli Sci., 4(1):9-16.

Akpaso MI, Atangwho IJ, Akpantah A, Fischer VA, Igiri A and Ebong E. 2011. Effect of Combined Leaf Extracts of Vernonia amygdalina (Bitter Leaf) and Gongronema latifolium (Utazi) on the Pancreatic $\beta$-Cells of Streptozotocin. Brit J Med \& Medical Rese., 1(1):24-34.

Anoka A 2013. Njan. Herbal Medicine in the Treatment of Malaria: Vernonia amygdalina: An Overview of Evidence and Pharmacology, Toxicity and Drug Testing, Prof. Bill Acree (Ed.), ISBN: 978-953-51-0004-1, InTech.2013.

Argheore EM, Makkar HPS, Becker K. 1998. Feed value of some browse plants from the central zone of Delta State Nigeria, Trop Sci., 38, 97-104.

Asaolu SS, Adefemi OS, Oyakilome IG, Ajibulu KE, Asaolu MF. 2012. Proximate and Mineral Composition of Nigerian Leafy Vegetable. J Food Res., 1, 3.

Cheng HY, Lin CC, Lin CC. 2002. Anti-herpes simplex virus type 2 activity of casuarinin from the bark of Terminalia arjuna Linn, Antiviral Res 55: 447-455.

Ekaluo UB, Ikpeme EV, Ekerette EE, Chukwu CI. 2015. In vitro Antioxidant and Free Radical Activity of Some Nigerian Medicinal Plants: Bitter Leaf (Vernonia amygdalina L.) and Guava (Psidium guajava Del.). Res J of Med Plant 9 (5): 215226.

Erasto P, Grierson DS, Afolayan AJ. 2007. Evaluation of Antioxidant activity and the fatty acid profile of the leaves of Vernonia amygdalina growing in South Africa. Food Chem., 104: 636-642.

Eyong UE, Agiang MA, Atangwho IJ, Iwara IA, Odey MO, Ebong PE. 2011. Phytochemicals and micronutrients composition of root and stem bark extracts of Vernonia amygdalina Del. J Med Medical Sci., 2(6): 900-903. 
Ezekiel A, Ojo AA, Ogunmodede OT, Adewumi DF. 2015. Antioxidant Activities and Nutritional Compostion of Vernonia amygdalina. Int J of Basic Appl Sci., 4(1): 9-16.

Farombi EO, Owoeye O. 2011. Antioxidant and chemopreventive properties of Vernonia amygdalina and Garcinia biflavonoid. Int J of Environ Res Pub Health 8: 2533-2555.

Foo RQ, Manogaran E, Gabriel AA. 2014. Antimicrobial and Antioxidant Studies of Vernonia Amygdalina. J Appli Pharm., 6(4): 360-371.

Ghamba PE, Balla H, Goje LJ, Halidu A, Dauda MD. 2014. In vitro antimicrobial activities of Vernonia amygdalina on selected clinical isolates. Int J Curr Micro Appli Sci., 3(4): 1103-1113.

God'swillhuff NA, Kayode OO, Adewale AO, Olabisi AS. 2010. Comparative Antioxidant, Phytochemical and Proximate Analysis of Aqueous and Methanolic Extracts of Vernonia amygdalina and Talinum triangulare. Pak J Nut., 9(3): 259-264.

Hamill FA, Apio A, Mubiro NK, Mosango M. 2000. Traditional herbal drugs of Southern Uganda. J Ethno-pharmaco., 70: 281300 .

Hamzah RU, Jigam AA, Makun HA, Egwin EC.2013. Antioxidant Properties of Selected African Vegetables, Fruits and Mushrooms: A Review. Intech 9: 203- 250.

Ho WY, Liang WS, Yeap SK, Beh BK, Yousr AHN. 2012. In vitro and in vivo antioxidant activity of Vernonia amygdalina water extracts, Afric J Biotech., 11(17): 4090-4094.

Huffman MA, Seifu M. 1989. Observation on the illness and consumption of a possibly medicinal plant Vernonia amygdalina (Del.), by a wild chimpanzee in the Mahale Mountains National Park, Tanzania. Primates 30: 51-63.

Huffman MA. 2003. Animal self-medication and ethno-medicine exploration and exploitation of the medicinal properties of plant. Proc Nut Soc., 62, 371-381.

Igile GO, Oleszek W, Jurzysta M, Burda S, Fanfunso M, Fasanmade AA. 1994. Flavonoids from Vernonia amygdalina and their antioxidant activities. J Agric Food Chem., 42: 2445-2448.

Item JA, Godwin EE, Mariam A, Mun FA, Mohd ZA. 2013. Antioxidant versus anti-diabetic properties of leaves from Vernonia amygdalina Del. growing in Malaysia. Food Chem., 141: 3428-3434.

Iwalokun BA, Efedede BU, Alabi-Sofunde JA, Oduala T, Magbagbeola OA, Akinwande A. 2006. Hepatoprotective and antioxidant activities of Vernonia amygdalina on acetaminophen-induced hepatic damage in mice. J Med Food 9: 524-539.

Izevbigie EB, Bryant JL, Walker A. 2004. A novel natural inhibitors of extracellular signal-regulated kinases and human breast cancer cell growth, Experimental Bio Med., 229: 163-169.

Kadiri O. 2015. Studies on the Chemical Composition, Functional and Antioxidant Properties of Carica Papaya (Pawpaw) Seed flour, Protein concentrate and Protein isolate, Protein concentrate and Protein isolate. M.sc thesis Department of Food Science and Technology, Obafemi Awolowo University, Ile-Ife, Nigeria, pp.75-78.
Kambizi L, Afolayan AJ. 2001. An ethnobotanical study of plants used for the treatment of sexually transmitted disease. J Ethnopharmaco., 77: 5-9.

Kelly O, Ehigbai I, Igbuan O, Nkeiruka E, Ogechukwu A, Omorede A and Ehimwenma SO. 2012. Comparative Antioxidant Activities of Extracts of Vernonia amygdalina and Ocimum gratissimum Leaves. J Agric Sci., 6(1): 13-20.

Kokwaro O.2009. Medicinal plants of East Africa. University of Nairobi Press, $3^{\text {rd }}$ Edition.

Lu Y, Foo IY. 2001 . Antioxidant activity of polyphenols from sage (Salvia officinalis). Food Chem., 75: $197-202$.

Minari JB. 2012. Hepatoprotective effect of methanolic extract of Vernonia amygdalina leaf. J Nat Prod., 5: 188-192.

Narayanan BA, Geoffrey O, Willingham MC, Nixon DW. 1999. Expression and its possible role in GI arrest and apoptosis in allergic acid treated cancer cells, Cancer Letters 136(2): 215 21.

Noumedem JA, Mihasan M, Kuiate JR, Stefan M, Cojocaru D, Dzoyem JP, Kuete V. 2013. In vitro antibacterial and antibioticpotentiation activities of four edible plants against multidrugresistant gram-negative species. BMC Complem Alter Med., 13(1): 190.

Nwanjo HU. 2005. Efficacy of aqueous leaf extract of Vernonia amygdalina on plasma lipoprotein and oxidative status in diabetic rat model. Niger J of Physio Sci 201-2:2, 30-42.

Nwanjo HU. 2014. Efficacy of aqueous leaf extract of Vernonia amygdalina on plasma lipoprotein and oxidative status in diabetic rat models, Niger J Physio Sci., 20: 39-42.

Oboh FOJ, Enobhayisobo EI. 2009. Effect of aqueous extract of Vernonia amygdalina leaves on plasma lipids of hyperlipidaemia adult male albino New Zealand rabbits. Afri Sci., 10, 4.

Oboh FOJ, Masodje HI. 2009. Nutritional and Antimicrobial Properties of Vernonia amygdalina Leaves. Int J Biomed Health Sci., 5 (2): 51-56.

Omoregie ES, Osagie AU. 2012. Antioxidant Properties of Methanolic Extracts of some Nigerian Plants on NutritionallyStressed Rats. Nigerian J Basic and Appl Sci., 20(1): 7-20.

Sodimic AL, Adebayo O, Oladele NO, Akinyemi O, Alabi OO, Emeghara UU, and Olumuyiwa SA. 2006. Comparative analysis of chemical composition in three species of bitter leaf (Vernonia spp). $\mathrm{J}$ of Res in Agric 3(3): 75-77.

Udochukwu U, Omeje FI, Uloma IS, Oseiwe ID. 2015. Phytochemical Analysis of Vernonia Amygdalina and Ocimum Gratissimum Extracts and their antibacterial activity on some Drug Resistant Bacteria. Am J of Res Comm., 3(5): 225-235.

WHO. 2003. Assessment and monitoring of antimalarial drug efficacy for the treatment of uncomplicated falciparum malaria. World Health Organization; Geneva., Switzerland 